\title{
Selected performance indices for assessment of polypropylene susceptibility to dyeing by pigments of different UV resistance
}

\author{
Marek Bieliński ${ }^{1), *)}$ (ORCID ID 0000-0002-2867-511X), Artur Kościuszko' ${ }^{1)}$ (0000-0003-1481-901X), Katarzyna Smolińska ${ }^{1)}$ \\ DOI: dx.doi.org/10.14314/polimery.2021.1.6
}

\begin{abstract}
This study presents an assessment of the effects of usage time for polypropylene (PP) experimental samples including those dyed with pigments of different UV resistance. A standard double cavity mold was used to create the samples by injection molding. Selected indices were analyzed in terms of color change (UV resistance of pigments), and UV radiation resistance of a PP polymer medium. The experiment revealed a significant impact of the accepted usage time and the type of dye concentrates on the indices characterizing the sample color change (CIELab) and a change in the structure and state of the PP medium surface.
\end{abstract}

Keywords: dyeing of plastics, color measurement, injection molding, UV resistance, structure of materials.

\section{Wybrane wskaźniki użytkowe oceny podatności polipropylenu na barwienie pigmentami o różnej odporności na UV}

Streszczenie: Oceniono wpływ czasu użytkowania próbek PP, w tym barwionych pigmentami o różnej odporności na UV, na wybrane wskaźniki użytkowe. Próbki doświadczalne wytworzono metodą wtryskiwania z zastosowaniem standardowej dwugniazdowej formy badawczej. Analizę wybranych wskaźników barwionych próbek przeprowadzono na podstawie: wyznaczonej zmiany barwy (odporność na UV pigmentów), a także odporności na promieniowanie UV nośnika polimerowego (PP). Wykazano istotny wpływ przyjętego w programie badań czasu użytkowania oraz rodzaju koncentratów barwiących na wartości wskaźników charakteryzujących barwę próbek (CIELab), a także strukturę i stan powierzchni tworzywa użytego jako nośnik (PP).

Słowa kluczowe: barwienie tworzyw, pomiar koloru, wtryskiwanie, odporność na UV, struktura tworzyw.

Current knowledge and technology make it possible to perform a thorough analysis of the process of dyeing of polymer materials. It is due to the fact that this technology is commonly used to provide the polymer products with esthetic and protective qualities. Dyed materials and the dyes come under rigorous assessment, depending on the application range. Industries such as: automotive, cosmetic and advertisement set very restrictive requirements concerning dyeing of the products. The standards related to coloring are also very high in construction industry, safety systems and interior architecture [1-3]. An increase in production of plastics and application of many new additives including dyes involves the need to identify the relations that occur in a material as a result of its modification. It applies mainly to chang-

1) University of Science and Technology, Faculty of Mechanical Engineering, Kaliskiego 7, 85-796 Bydgoszcz, Poland.

*) Author for correspondence: Marek.Bielinski@utp.edu.pl ing environmental conditions. In many applications the color plays an important informational role and its durability can also indicate a change in some of its properties due to UV radiation and the time of usage $[4,5]$. Disrespecting standards connected with resistance to UV radiation: light resistance (LE), weather resistance (WE) can lead to economic and reputational loss of companies and generate large financial losses for manufacturers [6]. Some problems connected with dyeing of materials are caused by intensive implementation of plastic recycling and the requirements included in the sustainable economy packet $[1,2,7]$. The idea of sustainable development involves a tendency to reduce dyeing of polymers used in popular disposable packages. This trend does not apply so much to cosmetic industry where colors still play a very important role [3, 8]. Implementation of an ecological balance based on an analysis of a product life cycle (LCA), considering both the material acquisition costs, the environmental impact, and the process 
energy consumption confirms benefits provided by the use of polymer materials in many applications and justifies high development indices for these branches [7,9]. Additionally, increasing interest in application of recycled materials indicates the need to take into account assessment of the aging processes that take place during successive utilizations [9-12]. Legal regulations that impose recovery of post life materials and their recycling pose a new challenge and additional requirements in all the application areas.

Aging of plastics usually leads to deterioration of the material properties. Its functional qualities gradually decrease through destruction and degradation. This phenomenon is irreversible and occurs in all stages of a polymer product life cycle. Due to constantly growing use of polymer materials (in many fields of economy) there is a need to identify the impact of external factors and the effects of processing on selected performance properties which eventually involves a necessity of continuous modification of the research methodology including identification of appropriate indices [9]. Aging processes, that is, all chemical and physical changes which lead to a change in functional qualities of utility polymers (especially esthetic, and mechanical ones), that occur in time, depend on both the base and auxiliary materials $[5,13,14]$.

Stability of the most important functional qualities of plastics largely depends on their resistance to the impact of environmental factors. In the case of processing with simultaneous dyeing, such indices as: discoloration repeatability, lack of migration, susceptibility to mixing and others need to be assessed [1, 15-17].

Characteristics of the aging processes, both in natural and laboratory conditions, mainly the impact of the aging time, UV radiation intensity and temperature, were explicitly described for polyolefin in the works of Czaja et al. [11, 12], and in the work of Wojtala [18].

The possibility to control heat resistance (stability) of materials through the use of auxiliary materials is often difficult due to the impact of the processing complex conditions $[14,19,20]$. Some problems are caused by occurrence of a bigger number of auxiliary materials (a few additives at the same time, multibatch) and their possible synergy $[10,18]$.

Assessment of the impact of external conditions on the functional qualities of plastic elements in correlation with the applied dyes is verified in a number of research works and usually applies to specific materials. Thus, in the works of Bociąga and Trzaskalska there is an analysis of the impact of ABS (acrylonitrile-butadiene-styrene) dyeing agents on toughness and impact resistance of molded pieces [19]. The impact of variable processing conditions on effects such as: color of the ABS sample surface, gloss and stability was evaluated as well [4, 19, 21]. Acceptance of an appropriate set of performance indices depends mainly on the assumed operation range of the plastics and can be increased by further properties, e.g. combustion resistance which are described for NBR mod- ified by heat stable pigments in the work of Pająk et al. [22]. The influence of UV radiation on PLA surface geometric structure with the use of dyes can be verified by means of research methods such as, e.g. SEM (Scanning Electron Microscopy), DSC (Differential Scanning Calorimetry), AFM (Atomic Force Microscopy) [23].

Selection of auxiliary materials, especially the type of dyes (organic, inorganic) and the manner of dyeing and an optimal choice of indexes has a direct influence on the costs of processing [24, 25]. At the same time, the requirements for dyed materials exposed to the impact of the environment for a long time are getting higher and higher.

There are special pigments used in processing, the so called fluorescent, metallic and pearl ones. Some of their functional qualities are characterized by lower values of selected indexes as compared to standard pigments. Selection of dyes from the "fluorescent" group should be closely connected with the predicted range and conditions of their operation [5, 15]. Application of pigments from this group is determined by the specificity of the optical effects they provide.

Advanced measurement methods such as DMTA (Dynamic Mechanical Thermal Analysis), FT-IR (Fourier Transform Infrared Spectroscopy), SEM are used for determination of the most important performance indices characterizing the structure of polymers. These methods are usually used for polymer materials or application areas such as biodegradable plastics [18, 23, 26]. Products that are expected to be used for a long time are analyzed by methods for prognosing of change in properties of the objects made of plastics [27]. Verification of the color correct choice is carried out with the use of a number of measurement devices for determination of characteristics of colors and is explicitly described in literature [8, 24, 28]. In special cases, e.g. for new plastics or pigments, durability is verified in the so called Florida test [5].

Modification of plastics and subsequent application of a big number of stabilizers or fillers, depends also on the auxiliary processes used in the material processing such as dosing mixing and drying. Technical systems responsible for accuracy of dosing also need to be modified [16, 17]. In these cases, the impact of the size and shape of the polymer material to be dosed (powders, agglomerates, micro-granulates or granulates, liquid additives) on the material staining repeatability is analyzed [18, 20].

Dyeing of polymer materials requires control of the color quality by its assessment both at the stage of pigment selection, concentrate composition preparation as well as the assessment of the final product color. The assessment is also carried out in order to determine the color durability during the usage [6, 9].

The study provides an analysis of the assessment of UV radiation resistance for the dyeing concentrates from the group of "fluorescent" masterbatches applied on a polypropylene medium. Two areas of UV radiation resistance analysis are considered in this study, one applies to the pigments and the other to the dyed medium. As is known, 
$\mathrm{T}$ a b 1 e 1. Characteristics of pigments used in the study

\begin{tabular}{c|c|c|c|c|c}
\hline Signature & Trade name & Color index & TB & LE & WE \\
\hline B1 & FLUOR GELB 40EA30 & S.Y.135 & 240 & $5 / 3-4$ & 0 \\
B2 & FLUOR ORANGE 40/RPC13 & S.Y.135+B.V.11+B.R.1 & 240 & $4 / 2$ & 0 \\
B3 & FLUOR ROT 40/EA35 & S.Y.135+B.V.11+B.R.1 & 240 & $4 / 2-3$ & 0 \\
B4 & ROT 40/3911. & P.R.178 & 300 & $8 / 8$ & $3-4$ \\
\hline
\end{tabular}

TB - heat resistance $\left({ }^{\circ} \mathrm{C}\right)$,

LE - light resistance/light resistance with white pigment additive (scale 1-8)

WE - weather resistance (scale 1-5).

it is important to be familiar with the resistance of particular components of the concentrate because functionality of the dye is determined by its weakest element. In this case, a group of special pigments of low UV resistance was analyzed. A research methodology which enables assessment of the color change, geometric features, the structure and state of the samples surfaces was used.

\section{EXPERIMENTAL PART}

\section{Materials}

Polypropylene Moplen HP 548R of Basell Orlen Polyolefins (Poland) with an antistatic agent and a nucleating agent were used in the study. Mass flow rate of homopolymer $M F R_{\left(230^{\circ} \mathrm{C}, 2.16 \mathrm{~kg}\right)}$ is equal to $23 \mathrm{~g} / 10 \mathrm{~min}$, according to the manufacture's declaration and the material is designed for injection molding.

Four different dyes used in the tests were produced by Lifocolor Farbplast Sp. z o.o. (Poland). The pigments were characterized by different UV radiation resistance. The pigment content in each of the masterbatches was 40 wt \%. Specifications of the applied auxiliary substances are presented in the Table 1.

\section{Sample preparation}

The samples of polypropylene containing particular dyeing substances were prepared by the injection method. The polypropylene granulate, initially mixed with a dyeing concentrate, was processed by means of an e-victory 110 injection molding machine of Engel company (Austria) with a short-circuit force equal to $1100 \mathrm{kN}$. The machine was equipped with a cold channel injection mold to enable production of universal research pieces with dimensions consistent with ISO 3167 standard (type A) [29] and a thermostatic device HB 140 Z1 of HB-THERM company (Switzerland). Dosing of fluorescent concentrates (B1-B3) was $6 \mathrm{wt} \%$, whereas, in the case of B4 dye 2 $w t \%$ was introduced. Temperature in particular zones of the plasticizing system was: $230^{\circ} \mathrm{C}$ (nozzle), $230^{\circ} \mathrm{C}, 220^{\circ} \mathrm{C}$, $200^{\circ} \mathrm{C}$, (barrel) $30^{\circ} \mathrm{C}$ (batch), respectively. The temperature of the injection mold was $40^{\circ} \mathrm{C}$, injection speed $50 \mathrm{~cm}^{3} / \mathrm{s}$. All the research parameters are presented in the Table 2. Examples of test samples containing different dyeing concentrates and a reference sample are shown in the Fig. 1.
T a b l e 2. Parameters of the injection molding process

\begin{tabular}{l|c}
\hline \multicolumn{1}{c|}{ Parameter } & Value \\
\hline Injection rate & $50 \mathrm{~cm}^{3} / \mathrm{s}$ \\
Injection pressure & $21 \mathrm{MPa}$ \\
Injection time & $1.52 \mathrm{~s}$ \\
Back pressure & $0.8 \mathrm{MPa}$ \\
Dosing speed & $0.3 \mathrm{~m} / \mathrm{s}$ \\
Holding time & $23 \mathrm{~s}$ \\
Holding pressure & $17 \mathrm{MPa}$ \\
Cooling time & $25 \mathrm{~s}$ \\
Batch temperature & $30^{\circ} \mathrm{C}$ \\
Barrel temperature I & $200^{\circ} \mathrm{C}$ \\
Barrel temperature II & $220^{\circ} \mathrm{C}$ \\
Barrel temperature III & $230^{\circ} \mathrm{C}$ \\
Nozzle temperature & $230^{\circ} \mathrm{C}$ \\
Mold temperature & $40^{\circ} \mathrm{C}$ \\
\hline
\end{tabular}

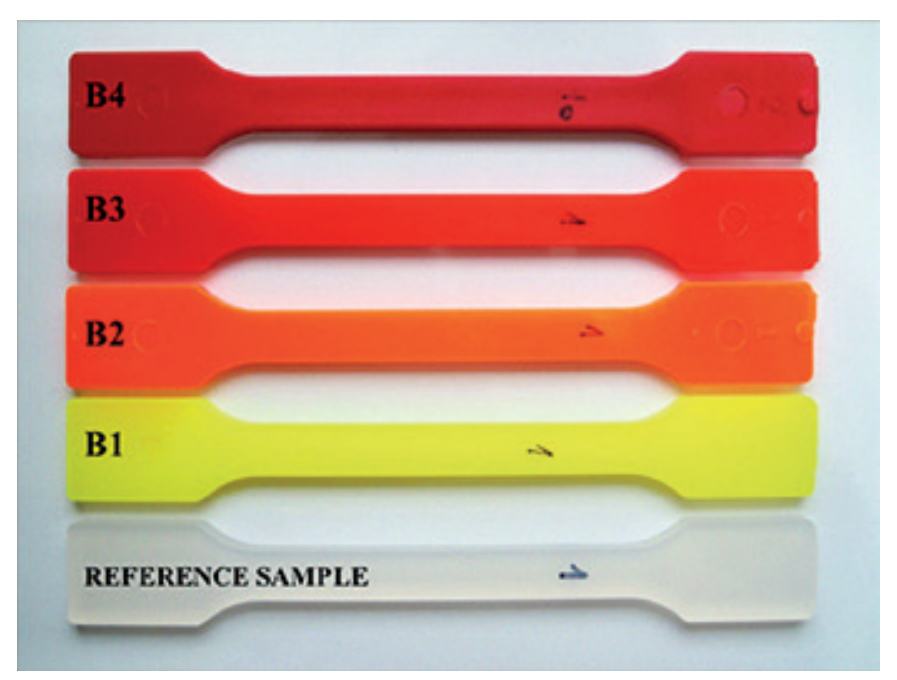

Fig. 1. Polypropylene samples containing different dying concentrates

\section{Methods of testing}

Aging of the samples was carried out in a climatic chamber KMF 115 of Binder company (Germany) equipped with UV lamps. The tests were conducted in the temperature equal to $50^{\circ} \mathrm{C}$ and at the moisture $65 \%$ $R H$. The total aging time of the dyed samples was $672 \mathrm{~h}$ (4 weeks). 
Every 168 h (1 week), colorimetric tests were performed with the use of spherical spectrophotometer Ci62 of X Rite company (USA ), to provide assessment of the samples color change due to their exposure to UV radiation. CIELab space was used for a description of the color. The test results for samples which did not undergo aging were a reference point for determination of the color change $(\Delta E)$. This parameter was determined from the below formula:

$$
\Delta E=\sqrt{(\Delta L)^{2}+(\Delta a)^{2}+(\Delta b)^{2}}
$$

where: parameter $L$ refers to brightness, parameter $a$ color from green to red and parameter $b$ color from blue to yellow.

In order to define possible changes that can occur in the polymer part dimensions during aging tests, the sample length was measured before and after the aging process (after 672 h). For this purpose, MarCal 16ER caliper of Mahr (Germany) was used. The results of the sample length measurements $\left(L_{T}\right)$ were used for calculation of the shrinkage $(S)$ :

$$
S=\frac{L_{F}-L_{T}}{L_{F}} \cdot 100 \%
$$

where: the corresponding dimension of the injection mold cavity is denoted as $L_{F}$

As part of the research methodology for assessment of a PP medium UV radiation resistance, samples of undyed polypropylene were tested with the use of the differential scanning calorimetry method (DSC) for particular stages of the aging process. DSC 214 Polyma of Netzsch company (Germany) was used for this purpose. Samples of mass $10-12 \mathrm{mg}$ were heated in nitrogen atmosphere up to $230^{\circ} \mathrm{C}$ in order to erase the thermal and mechanical history. After two minutes of heating they were cooled down to $25^{\circ} \mathrm{C}$. The rate of heating and cooling was $10^{\circ} \mathrm{C} / \mathrm{min}$. Next, after $2 \mathrm{~min}-$ utes, the samples were reheated up to temperature $230^{\circ} \mathrm{C}$.
Photographs of PP samples before aging and after 4 weeks of exposure to UV radiation were taken using the Olympus LEXT OLS 4000 confocal microscope. Moreover, this device was used to determine the surface roughness of the samples. The measurement was carried out over a section of $625 \mu \mathrm{m}$.

\section{RESULTS AND DISCUSSION}

Table 3 shows parameters $L, a, b$, which were recorded during calorimetric tests of the dyed samples after successive periods of aging. An analysis of the test results showed that extension of the exposure time of PP molded pieces containing B1 dye causes a definite decrease in $L$ parameter (lightness) starting with the value of 66.26 for the not aged sample to 55.65 after $672 \mathrm{~h}$ (4 weeks) of aging. Moreover, a decrease in the value of $b$ parameter from 64.47 (not aged samples) to 34.69 (672 h) can be observed which indicates a gradual shift of color into gray.

In the case of samples with B2 dye, the biggest changes after $672 \mathrm{~h}$ of aging were recorded for parameters $a$ and $b$, which also indicates a shift of the color into grey. The value of $a$ parameter decreased from 55.69 to 42.50 , and the value of $b$ parameter decresed from 46.43 to 37.30 . Aging of PP samples containing B3 dye causes a change in only a parameter whose value changes from 43.03 (without aging) to $34.80(672 \mathrm{~h})$. The highest UV radiation resistance was found for B4 dye for which changes in the three parameters were found to be insignificant.

Additionally, a shift in the sample color was expressed by the change of $\Delta E$ parameter with the time of the sample exposure to UV radiation (Fig. 2). The presented values of this index also confirm that the samples with B4 dye are characterized by the highest UV radiation resistance. After 4 weeks of exposure, the value of $\Delta E$ for this composition reached 1.26 , which indicates that differences in the color between the sample aged for $672 \mathrm{~h}$ and an unaged sample can be noticed only by an experi-

\begin{tabular}{|c|c|c|c|c|c|c|}
\hline \multirow{2}{*}{ Type of dye } & \multirow{2}{*}{ Parameter } & \multicolumn{5}{|c|}{ Time of measuring, $\mathrm{h}$} \\
\hline & & 0 & 168 & 336 & 504 & 672 \\
\hline \multirow{3}{*}{ B1 } & $L$ & 66.26 & 58.01 & 61.34 & 56.74 & 55.65 \\
\hline & $a$ & -16.78 & -18.72 & -15.21 & -15.50 & -13.58 \\
\hline & $b$ & 64.47 & 47.68 & 47.73 & 38.00 & 34.69 \\
\hline \multirow{3}{*}{ B2 } & $L$ & 54.53 & 52.47 & 53.42 & 52.23 & 51.68 \\
\hline & $a$ & 55.69 & 49.27 & 49.27 & 44.80 & 42.50 \\
\hline & $b$ & 46.43 & 43.11 & 43.86 & 40.18 & 37.30 \\
\hline \multirow{3}{*}{ B3 } & $L$ & 39.46 & 37.88 & 38.94 & 38.47 & 38.98 \\
\hline & $a$ & 43.03 & 37.27 & 38.29 & 34.88 & 34.80 \\
\hline & $b$ & 23.62 & 21.34 & 22.80 & 21.81 & 22.40 \\
\hline \multirow{3}{*}{ B4 } & $L$ & 43.00 & 43.64 & 43.78 & 43.93 & 43.94 \\
\hline & $a$ & 52.28 & 52.15 & 51.84 & 51.76 & 51.69 \\
\hline & $b$ & 29.95 & 29.94 & 29.68 & 29.48 & 29.35 \\
\hline
\end{tabular}

$\mathrm{T}$ a $\mathrm{b} l \mathrm{e}$ 3. Values of $L, a, b$ parameters for samples after aging 


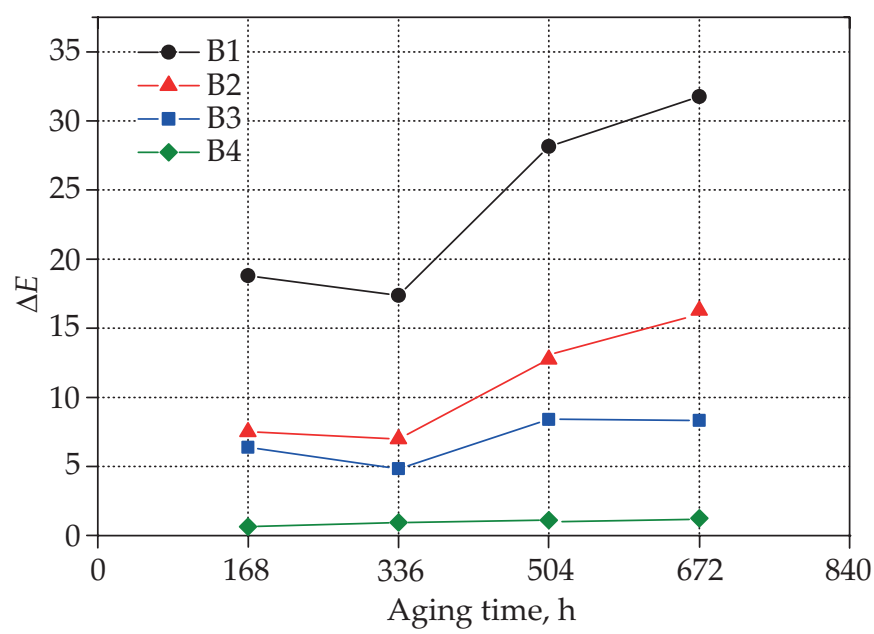

Fig. 2. Changes in $\Delta E$ parameters of dyed samples at different stages of the aging process

enced observer. For the other compositions, $\Delta E$ reached a value $>5$, already after $168 \mathrm{~h}$ of the aging process which means a distinct color change.

The introduction of masterbatches to the polypropylene matrix resulted in a slight increase in the value of processing shrinkage compared to undyed polypropylene (Table 4). This effect was observed for all types of dyes used. The greatest increase was recorded for samples modified with B1 and B2 dye. The shrinkage value in this case was $1.60 \%$, while the shrinkage for the PP samples was equal to $1.48 \%$.

Changes in the processing shrinkage values of PP samples aged for $672 \mathrm{~h}$, compared to not aged samples, may indicate the occurrence of the post-molding shrinkage phenomenon [30]. This effect may also be the result of structural changes taking place in the material as a result of exposure to UV radiation. Calorimetric tests of the
T a b l e 4. Value of shrinkage of dyed PP molded pieces before and after aging

\begin{tabular}{c|c|c}
\hline \multirow{2}{*}{ Type of dye } & \multicolumn{2}{|c}{ Shrikage, \% } \\
\cline { 2 - 3 } & Before aging & After aging $(672 \mathrm{~h})$ \\
\hline Reference sample & 1.48 & 1.71 \\
B1 & 1.60 & 1.75 \\
B2 & 1.60 & 1.76 \\
B3 & 1.56 & 1.79 \\
B4 & 1.55 & 1.78 \\
\hline
\end{tabular}

aged samples were carried out in order to evaluate possible structural changes occurring in the polypropylene matrix of the colored moldings.

The obtained results (Fig. 3) indicate a slight influence of the aging process on the thermal properties of the samples in comparison to the unaged material. The course of all recorded DSC melting curves is very similar. Moreover, no significant differences in the melting point were observed between the analyzed samples (Table 5). The value of this parameter ranged from $164.8^{\circ} \mathrm{C}$ for the sample aged for $168 \mathrm{~h}$ to $167^{\circ} \mathrm{C}$ for the sample aged for $504 \mathrm{~h}$. The value of the enthalpy of melting PP aged for

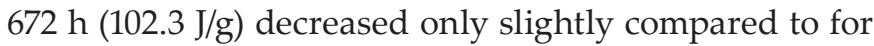
unaged material (107.1 J/g). The recorded changes in thermal properties of aged PP are relatively small compared to the effects that can be observed after several months of aging in natural conditions [31]. Therefore, it can be concluded that the impact of UV radiation is only superficial, which results in a change of color of samples colored with pigments with low resistance to radiation.

The samples of a polypropylene medium (not dyed) not aged and aged for 4 weeks were analyzed in a climatic chamber with the use of a confocal microscope.
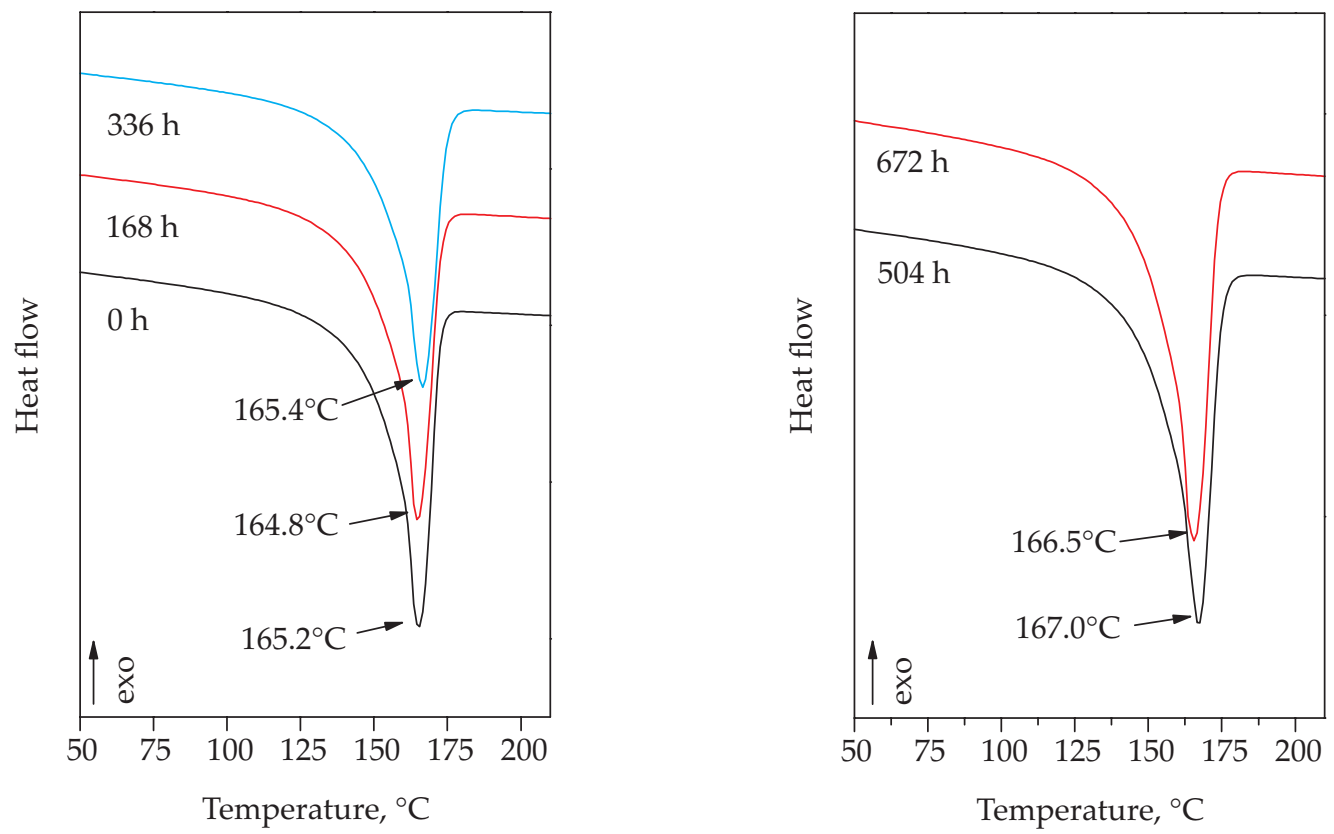

Fig. 3. DSC melting curves of PP samples aged for different periods of time 
T a b l e 5. Thermal properties of aged polypropylene

\begin{tabular}{c|c|c}
\hline $\begin{array}{c}\text { Aging time } \\
\mathrm{h}\end{array}$ & $\begin{array}{c}\text { Melting } \\
\text { temperature, }{ }^{\circ} \mathrm{C}\end{array}$ & $\begin{array}{c}\text { Melting entalphy } \\
\mathrm{J} / \mathrm{g}\end{array}$ \\
\hline 0 & 165.2 & 107.1 \\
168 & 164.8 & 106.9 \\
336 & 165.4 & 104.2 \\
504 & 167.0 & 103.6 \\
672 & 166.5 & 102.3 \\
\hline
\end{tabular}

As early as after 3 weeks, slight, transverse cracks could be observed on the surface. These cracks increased over the next week of UV radiation. They were visible even to the naked eye. Figure 4 shows changes of the sample surface and appearance of mutually parallel lines with sparse branches.

The surface of the samples that had not undergone the process of aging was smooth and had no visible cracks.
In the case of samples that had been aged (max. time of UV radiation) numerous cracks were observed all over the surface including the side and the bottom surfaces. On the edges where more fractures were found, and their branches connected with each other, the external layer of the material was susceptible to crushing. The results of roughness measurements (presented in Fig. 5), characterized by $R_{a}$ index, have confirmed the changes that occurred on the surface of PP samples.

Places in which the surface is mapped are marked in red in Figs. $4 \mathrm{~b}$ and $4 \mathrm{~d}$. Irregularities of the sample which had not been aged were found to be insignificant and ranged within $1 \mu \mathrm{m}$ (Fig. $5 \mathrm{a}$ ), they could partly be caused by mapping of the tool cavity roughness. On the aged samples, fractures were of different depth reaching from 2 to $4 \mu \mathrm{m}$ (Fig. 5b). Distinct hollows were observed on the aged samples around the places of crack occurrence. In front of each of them there were deformations formed by the surface cracking.
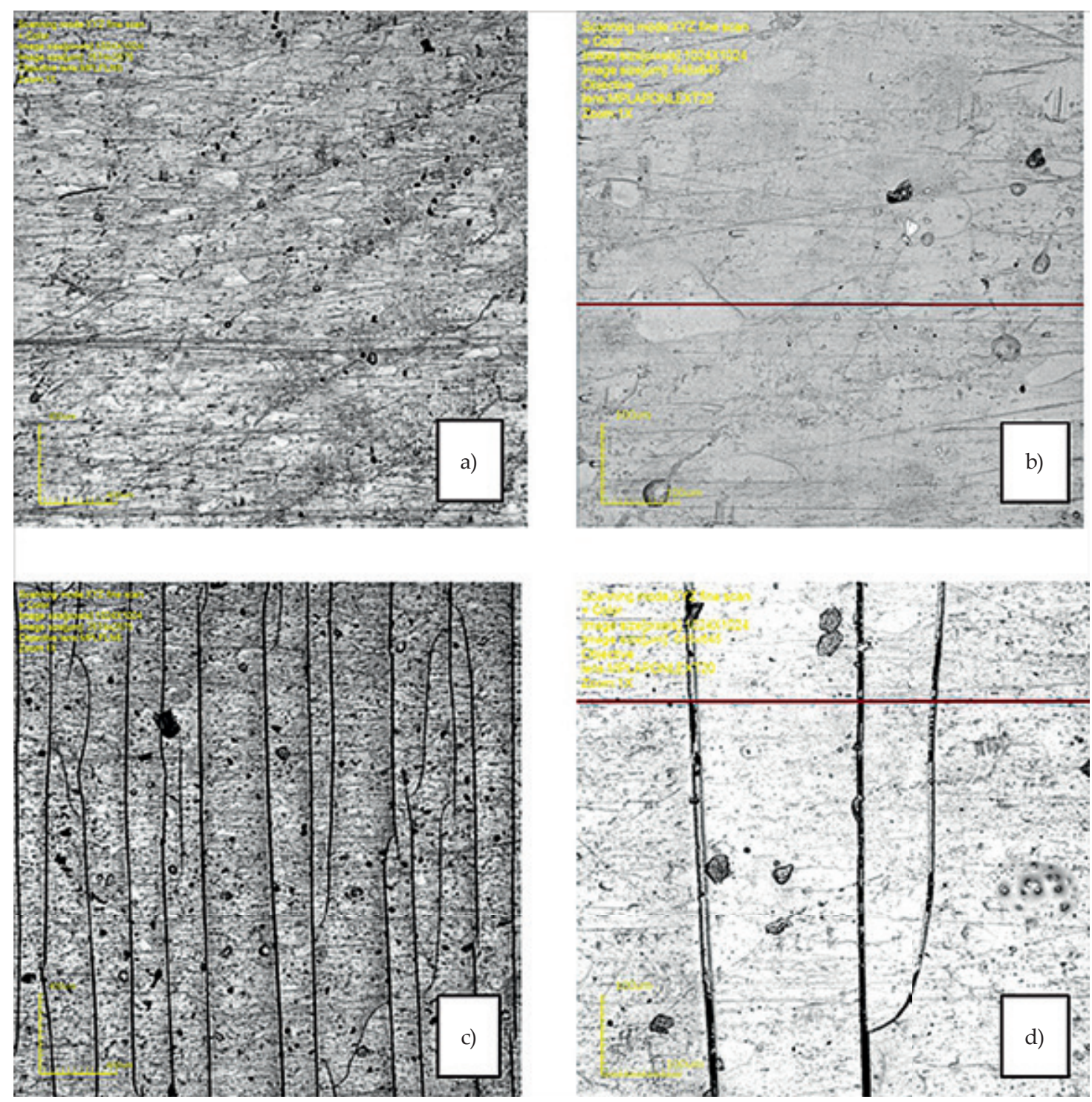

Fig. 4. Pictures of a polypropylene reference sample surface: $\mathrm{a}, \mathrm{b}$ ) before, c) after $672 \mathrm{~h}$ aging, d) after $672 \mathrm{~h}$ aging; pictures a), c) magnification $5 x$, picture b), d) magnification $20 x$ 


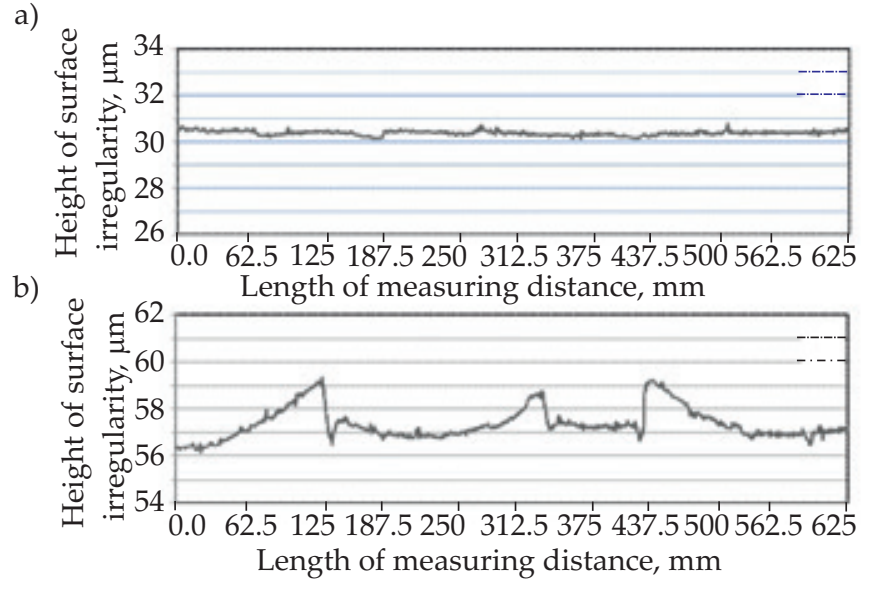

Fig. 5. Surface irregularities of PP samples: a) unaged, b) aged for $672 \mathrm{~h}$

\section{CONCLUSIONS}

The study of functional quality of dyed plastics was divided into two areas, one was concerned with UV radiation resistance of pigments and the other with a polymer medium. Colorimetric tests confirmed different dynamics of the color change of fluorescent pigments as compared to high UV resistance pigments. It was proven that deterioration of performance characteristics determined by the colorimetric method can verify this susceptibility in a relatively simple way. The tests have also confirmed a large influence of the aging phenomena on properties of polypropylene medium which in the case of a longer exposure time to UV radiation indicates that the material needs additional stabilization. Pigments of higher UV radiation resistance are likely to lose the original functional qualities of the polypropylene medium. Application of pigments with higher UV resistance, involves the need to level the dynamics of changes that occur in a polymer medium with color changes that occur in pigments. Stability and equal ageing resistance of both the medium and the dye are considered to belong to an important group of indices characterizing performance characteristics of the polymer materials.

\section{REFERENCES}

[1] Kozera-Szałkowska A.: Polimery 2019, 64, 751. http://dx.doi.org/10.14314/polimery.2019.11.3

[2] Piekarska E.: Przetwórstwo Tworzyw 2009, 15, 98.

[3] Plastics Europe Raport 2018.

[4] Trzaskalska M.: „Przetwórstwo tworzyw polimerowych. Aspekty technologiczne i nowe trendy"(Ed. E. Sasimowski), Vol. 2, pp. 52-71, Monografie Politechnika Lubelska 2016.

[5] Kremer J., Hahn W.: "Einfärben von Kunststoffen: mit Masterbatch", Vogel Buchverlag, Wurzburg 2001.

[6] Lapresa G.: "Industrielle Kunststoff Coloristik", Hanser, Munchen, Wien 1998.

[7] Kijeński J.: Polimery 2019, 64, 725. http://dx.doi.org/10.14314/polimery.2019.11.1
[8] Skowroński Ł., Wachowiak A.A., Wachowiak W.: Applied Surface Science 2017, 421, 794. https://doi.org/10.1016/j.apsusc.2017.03.276

[9] Bieliński M., Sykutera D., Kościuszko A., Czyżewska P.: Przetwórstwo Tworzyw 2016, 172, 365.

[10] Brzozowska-Stanuch A., Rabiej S., Fabia J., Nowak J.: Polimery 2014, 59, 308. http://dx.doi.org/10.14314/polimery.2014.302

[11] Kosmalska D., Kaczmarek H., Malinowski R., Bajer K.: Polimery 2019, 64, 317. http://dx.doi.org/10.14314/polimery.2019.5.1

[12] Sobków D., Czaja K.: Polimery 2003, 48, 627. http://dx.doi.org/10.14314/polimery.2003.627

[13] Sobków D., Sudoł M., Czaja K.: „Fotooksydacyjne starzenie stabilizowanego polipropylenu $\mathrm{w}$ warunkach laboratoryjnych i poligonowych", Uniwersytet Opolski 2007.

[14] Kaczmarek H., Kosmalska D., Malinowski R., Bajer K.: Polimery 2019, 64, 239. http://dx.doi.org/10.14314/polimery.2019.4.1

[15] Harper C.A.: "Handbook of Plastics Technologies: The Complete Guide to Properties and Performance" (McGraw-Hill Professional), $2^{\text {nd }}$ Edition, Access Engineering 2006.

[16] Bieliński M., Burzyński P.: Polimery 2004, 49, 275. http://dx.doi.org/10.14314/polimery.2004.275

[17] Sykutera D., Bieliński M.: Polimery 2019, 64, 795. http://dx.doi.org/10.14314/polimery.2019.11.8

[18] Wojtala A.: Polimery 2001, 46, 120. http://dx.doi.org/10.14314/polimery.2001.120

[19] Trzaskalska M., Palutkiewicz P., Bociąga E.: Polimery 2018, 63, 791. http://dx.doi.org/10.14314/polimery.2018.11.7

[20] Bociąga E., Trzaskalska M.: Przetwórstwo Tworzyw 2015, 21, 214.

[21] Bociąga E., Trzaskalska M.: Polimery 2016, 61, 544. http://dx.doi.org/10.14314/polimery.2016.544

[22] Pająk A., Rybiński P., Dobrzyńska R. et al.: Polimery 2015, 60, 396. http://dx.doi.org/10.14314/polimery.2015.396

[23] Stepczyńska M., Moraczewski K., Malinowski R., Żenkiewicz M.: Polimery 2017, 62, 193. http://dx.doi.org/10.14314/polimery.2017.163

[24] Chorobiński M., Skowroński Ł., Bieliński M.: Polimery 2019, 64, 690. http://dx.doi.org/10.14314/polimery.2019.10.6

[25] Charvat A. Robert: "Coloring of Plastics: Fundamentals Second Edition", John Wiley \& Sons, Inc., Hoboken, New Jersey 2004.

[26] Stepczyńska M.: Polimery 2015, 60, 385. http://dx.doi.org/10.14314/polimery.2015.385

[27] Jachowicz T., Sikora R.: Polimery 2006, 51, 177. http://dx.doi.org/10.14314/polimery.2006.177

[28] Gilewicz P., Rutowicz J., Frydrych I. et al.: Biuletyn Wojskowej Akademii Technicznej 2014, 63, 79.

[29] Sykutera D., Wajer Ł., Kościuszko A. et al.: Macromolecular Symposia 2018, 378, 1700056. 
http://dx.doi.org/10.1002/masy.201700056

[30] Kościuszko A., Czyżewski P., Wajer Ł. et al.: Polimery 2020, 65, 99.

http://dx.doi.org/10.14314/polimery.2020.2.3
[31] Wąsicki A., Kościuszko A.: Polimery 2011, 56, 401. http://dx.doi.org/10.14314/polimery.2011.401

Received 27 IV 2020. 